\title{
Maladie de Steinert ou dystrophie myotonique «une maladie pas comme les autres»
}

\author{
Bernard Lemieux
}

Dans un éditorial de l'Union Médicale (Tome 90, août 1961) portant sur la création d'un centre de neurogénétique, le défunt docteur André Barbeau soulignait: «la province de Québec, par son caractère ethnique et démographique particulier, est devenue un des rares endroits au monde où peuvent encore s'étudier, presqu'à l'état pur, certaines maladies héréditaires ou familiales du système nerveux». Le symposium dont le compte rendu est présenté dans les articles qui suivent, démontre bien ce fait. Organisé par le département de physiothérapie de la faculté de médecine de l'Université Laval avec le support de l'Association de dystrophie musculaire du Canada, ce symposium, qui a eu lieu le 6 décembre 1986, portait sur la dystrophie myotonique de Steinert (DMS), l'une des maladies héréditaires auxquelles faisait alors mention A. Barbeau. Cette rencontre avait comme objectif de réunir différents intervenants québécois intéressés à l'étude de cette maladie afin de partager les connaissances et de susciter des collaborations.

Maladie multisystémique transmise selon le mode autosomal dominant, la DMS se caractérise par une grande variabilité d'expression, particulièrement pour ce qui est de l'âge d'apparition des premiers symptômes, de leur nature et de leur sévérité. Sa prévalence moyenne au Québec est environ 10 fois supérieure à celle rapportée ailleurs dans le monde et elle est même beaucoup plus élevée dans certaines régions de la province. Au Québec, la DMS est en conséquence la plus fréquente des dystrophies musculaires, tant chez l'adulte que chez l'enfant. A ce jour, les bases biochimiques et physiopathologiques primaires et secondaires de cette maladie sont encore inconnues. Ceci implique qu'il n'existe pas de traitement curatif pour cette maladie qui doit alors être traitée pour sa symptomatologie. Plusieurs doivent également recourir au conseil génétique afin de connaître leur risque de transmettre le gène responsable ou d'être eux-mêmes atteints par la maladie.

Des progrès considérables ont été réalisés au cours des 25 dernières années dans la caractérisation de la DMS et ce, plus particulièrement depuis environ 5 ans.

En effet, la biologie moléculaire, utilisée dans une approche multidisciplinaire, permet depuis peu de prédire l'état de porteur du gène de la DMS et d'effectuer du diagnostic prénatal. Les travaux en cours mèneront incessamment à l'identification du défaut génique responsable. Ceci permettrait entre autres d'établir les fondements de travaux portant sur la recherche de traitement(s) curatif(s).

Comme au Québec, tout clinicien, qu'il soit médecin ou chirurgien, omnipraticien ou spécialiste, est susceptible dans sa pratique quotidienne d'avoir à établir un diagnostic de maladie de Steinert et ce quelque soit l'âge de son patient, les connaissances actuelles et les particularités propres à la DMS au Québec doivent leur être accessible et être connues également des autres professionnels de la santé. C'est ce qui, fondamentalement, a motivé la publication de ce symposium.

Quoique qu'une place importante de ce symposium a été alouée à la discussion de problèmes rencontrés par les intervenants impliqués dans l'étude ou l'encadrement de sujets affectés par la DMS au Québec, les articles ci-joints ne résument que l'essentiel des thèmes présentés.

C'est ainsi qu'après un message de bienvenue du docteur Marc Bouchard, vice-doyen à la recherche, le docteur Marie Christine Thibault, organisatrice du symposium, a présidé la première partie portant principalement sur les aspects démographiques et cliniques. Le docteur Claude Laberge, président du Réseau de Médecine Génétique du Québec, a rapidement été conduit à développer le problème de la DMS au Québec quant à sa prévalence exceptionnellement élevée quoique à des degrés différents dans deux régions, soit les Cantons de l'Est et le Saguenay-Lac St-Jean. Cette dernière est depuis quelques années chapeautée par une enquête exceptionnelle dirigée par monsieur Gérard Bouchard, chercheur en histoire des populations à l'Université du Québec de Chicoutimi, qui a fait un exposé admirable sur la diffusion du gène de DMS au Saguenay-Lac St-Jean.

A l'aide d'illustrations convaincantes, le docteur Jean-Pierre Bouchard, professeur de neurologie, s'est ensuite attaché à décrire succinctement les aspects musculaires et extra-musculaires de cette affection multisystémique, d'un diagnostic généralement facile. Toutefois, l'expressivité variable dans l'âge d'apparition (de la naissance jusqu'à l'âge de 70 ans et plus) et dans la sévérité du phénotype en complique parfois le diagnostic clinique. Ces deux caractéristiques cliniques obligent ainsi constamment à parfaire une enquête familiale exhaustive. 
Le docteur Jean Mathieu, neurologue et directeur de la clinique de dystrophie musculaire de Chicoutimi, a par la suite exposé son expérience sur la détection des formes frustres, peu ou présymptomatiques qui sont fréquemment rencontrées lors de telles enquêtes familiales et qui rendent l'élaboration d'un conseil génétique plus ardu. De plus, les docteurs Gaétan Paris, Rachel Laframboise et Jean-Pierre Bouchard ont extrait dans l'éventail des manifestations cliniques les complications gynécoobstétriques souvent mal connues chez les patients atteints de la DMS.

Le groupe ECOBES, département des sciences humaines, CEGEP de Jonquière, a divulgué deux informations pertinentes de cette maladie, soit les caractéristiques socio-économiques particulières et peu connues (présentation de M. Michel Perron), soit les énigmes de la fécondité et de la nuptialité (présentation de Mme Suzanne Veillette). Les résultats de leurs travaux sont admirablement exposés dans un rapport de recherche disponible au CEGEP de Jonquière.

Le docteur Sital Moorjani de l'Université Laval a ensuite présenté les résultats de travaux sur le métabolisme des lipides et des lipoprotéines en relation avec le polymorphisme de l'apolipoproptéine E (APOE) dans les familles de DMS. L'utilisation de l'APOE comme marqueur phénotypique par cette même équipe, aurait une liaison assez étroite avec le gène DMS, avec un taux de recombinaison de $6 \%$ dans des familles canadiennes françaises.
Par la suite, le docteur Claude Laberge est venu exposer le problème de moins en moins controversé de l'homogénéité génétique de cette affection en face d'une hétérogénéité clinique «apparente».

Enfin, docteur Marie Christine Thibault, présenta l'apport nouveau de la génétique moléculaire appliquée à cette affection. A l'instar d'autres maladies neurologiques, telles la chorée de Huntington et la dystrophie musculaire de Duchenne, la stratégie de la génétique inverse y est de plus en plus utilisée et permet maintenant, sans connaître le gène muté ni même son produit, d'arriver par voie indirecte au diagnostic prénatal et à une prédiction génétique inégalée. Actuellement, des sondes périgéniques de DNA, les unes pour l'apolipoprotéine C2, l'autre pour la séquence anonyme D19S19, sont reconnues comme étant étroitement liées au gène de la DMS localisé sur le bras long du chromosome 19 près de son centromère (19q13.1). Cet exposé largement documenté et bien animé par le docteur Thibault s'est terminé par une discussion très approfondie dominée par les espoirs actuellement placés dans cette stratégie.

Il est hors de doute que l'acceuil réservé à ce type de symposium témoigne de sa grande utilité, et il faut espérer aussi, tel que souligné dans le mot de clôture par docteur Carol Richards, directrice de la section de physiothérapie, qu'on aura à coeur de renouveler l'expérience et d'organiser d'autres rencontres sur la dystrophie myotonique de Steinert. 


\title{
EDITORIAL
}

\section{Steinert's Disease or Myotonic Dystrophy "A Disease Unlike Others"}

\author{
Bernard Lemieux
}

In an editorial in the L'Union Médicale (Volume 90, August 1961) on the creation of a Neurogenetic Center, the late Dr. André Barbeau emphasized that "The Province of Québec because of its particular ethnic and demographic characteristics has become one of the rare places in the world where certain hereditary or familial diseases of the nervous system can still be studied almost in a pure state".

Among these hereditary diseases, one, well known to neurologists, is the Myotonic Dystrophy of Steinert (MyD). On the 6th of December 1986, under the initiative of the Department of Physiotherapy of the Faculty of Medicine of Laval University, and the support of the Muscular Dystrophy Association of Canada, a Steinert's Symposium was held which permitted a meeting of numerous health professionals.

A group of speakers from Québec and Chicoutimi laid stress on certain aspects (clinical, therapeutic, demographic and genetic) of this disease. It is a multisystemic disease with autosomal dominant transmission, noteworthy for the grand variation both in the age of onset and its degree of severity. The mean prevalence in Quebec is about ten times greater than elsewhere in the world, with, most exceptionally, a particularly high regional concentration. It is thus the most frequent of all the muscular dystrophies in Québec as much in adults as in children. The biochemical and physiological bases, both primary and secondary, are still unknown. In view of the absence of curative treatment, it is imperative that these patients be offered symptomatic, and above all, preventive treatments within the frame-work of a multidisciplinary approach.

During the last 25 years, considerable progress has been documented, as witnessed by the many publications and monographs on this subject. For more than 5 years, the tools of molecular biology have allowed us to foresee the possibility of prenatal diagnosis and genetic prediction, and finally, a hope for curative treatment.

It is no exaggeration to recall that each clinician, whether physician or surgeon, family practitioner or specialist, during his daily practice may have to make the diagnosis of Steinert's Disease in a patient at any age. It is thus of the greatest interest that the actual knowledge and characteristics of MyD in Québec should be published and thus rendered accessible to the greatest possible number of physicians and health professionals in the Province.
Beside the themes and formal presentations, much time was reserved for questions and replies, which allowed much discussion concerning daily problems encountered by health professionals. The reader of the pages which follow will readily understand that these reflect only the presentations at this meeting and that, because of the relatively short times that were allocated, the speakers could not make a complete revision of the subjects entrusted to them. Thus, after greetings from Doctor Marc Bouchard, the Vice-Dean of research, Doctor MarieChristine Thibault who organized the Symposium, presided over the first part bearing principally on demographic and clinical aspects. Doctor Claud Laberge, President of The Québec Network of Genetic Medicine, rapidly developed the problem of MyD in Québec, both because of its exceptionally high prevalence at different degrees in two regions: the Eastern Townships and the Saguenay-Lac St-Jean region. This latter has during several years been the subject of an intensive inquiry directed by Monsieur Gérard Bouchard, researcher in population history at the University of Québec at Chicoutimi, who gave an admirable exposition on the diffusion of the MyD gene in this area.

Using most convincing illustrations, Doctor Jean-Pierre Bouchard, professor of neurology, then followed with a succinct description of the muscular and extra-muscular aspects of this multisystemic affliction, which is generally easily diagnosed. However, the variable expression of the age of onset (from birth up to the age of 70 years and over) and the severity of the phenotype sometimes complicate the clinical diagnosis. These two clinical characteristics necessitate an exhaustive family history. Doctor Jean Mathieu, neurologist and director of the Muscular Dystrophy Clinic of Chicoutimi spoke of his experience on the detection of "formes frustres", asymptomatic or presymptomatic, which are frequently encountered during family studies and make the development of genetic counselling more difficult. Furthermore, Doctors Gaétan Paris, Rachel Laframboise and Jean-Pierre Bouchard selected from the gamut of clinical manifestations those little known gyneco-obstetric complications in patients with MyD.

The ECOBES Group of the Department of Human Sciences, CEGEP of Jonquière revealed two inquiries pertinent to this disease, the particular socio-economic characteristics which are little known (by Monsieur Michel Perron) and the enigma of 
fertility and nuptiality (presented by Madame Suzanne Veillette). The results of their work are very well presented in a research report available at the CEGEP of Jonquière.

Doctor Sital Moorjani of Laval University then discussed the studies on the metabolism of lipids and lipoproteins in relation to the polymorphism of the apolipoprotein $\mathrm{E}$ (APOE) in MyD patients. Moreover, the utilisation of APOE as phenotypic marker by this group is shown to be at very close linkage with the MyD gene, with a recombination frequency of $6 \%$ in French Canadian families.

Following this, Doctor Laberge discussed the problem, which is becoming less and less debated, of the genetic homogeneity of this disease in the face of an apparent clinical heterogeneity.

Finally, Doctor Marie-Christine Thibault, presented the new approach of molecular genetics applied to this disease. As in the case of other neurological diseases, such as the Huntington's chorea and Duchenne Muscular Dystrophy, the strategy of "reverse" genetics is more and more used and enables us, without knowing the mutative gene or even its product, to arrive by an indirect method at a prenatal diagnosis and to an unmatched genetic prediction. Today, perigenic DNA probes, for apolipoprotein $\mathrm{C} 2$ and for the anonymous DNA sequence D19S19, recognize loci closely linked to the MyD gene localized on the long arm of chromosome 19 close to its centromere (19q13.1). This lively presentation finished with a detailed discussion dominated by the hopes currently placed in this strategy.

There is no doubt that the reception given to this type of symposium bears witness to its great usefulness, and we must also hope, as Dr. Carol Richards, Directrice of the Section of Physiotherapy, stressed during the closing words, to benefit from the organization of further meetings on the MyD of Steinert. 